\title{
Effect of Removal of Garlic Mustard (Alliaria petiolata, Brassicaeae) on Arbuscular Mycorrhizal Fungi Inoculum Potential in Forest Soils
}

\author{
Roger C. Anderson ${ }^{*}, 1$, M. Rebecca Anderson ${ }^{1}$, Jonathan T. Bauer ${ }^{2}$, Mitchell Slater ${ }^{1}$, Jamie Herold ${ }^{1}$, \\ Patrice Baumhardt ${ }^{3}$ and Victoria Borowicz ${ }^{1}$ \\ ${ }^{1}$ School of Biological Sciences, Illinois State University, Normal, Illinois 61790-4120, USA \\ ${ }^{2}$ Department of Biology, Indiana University, 107 S Indiana Ave Bloomington, Indiana 47405, USA \\ ${ }^{3}$ Department of Biological Sciences, Purdue University, 915 W. State Street West Lafayette, IN 47907-2054, USA
}

\begin{abstract}
Garlic mustard (Alliaria petiolata), a biennial species, is considered to be among the most troublesome of the invasive plants in the Eastern Deciduous forest of North America. It has been shown to prevent or reduce mycorrhizal colonization of native herbaceous ground layer plants and trees in these forests. It is estimated that $70-90 \%$ or more of herbaceous native ground layer plant species form associations with arbuscular mycorrhizal fungi (AMF). Loss of the mycorrhizal association can reduce growth, reproductive success, and competitiveness of plant species. Using a corn root bioassay, we examined the effect of garlic mustard removal on the soil AMF mycorrhizal inoculum potential (MIP), in control plots and plots that had second-year garlic mustard removed annually for the past five years (2005-2009). Removal treatment plots had significantly $(\mathrm{P}=0.0240, \mathrm{df}=28)$ greater MIP than control plots $(25.72 \pm 2.26 \%$ and $18.29 \pm 2.04 \%$, respectively). MIP was negatively correlated with cover of garlic mustard $\left(\mathrm{r}^{2}=0.1325, \mathrm{P}<0.05, \mathrm{df}=30\right)$, which accounted for $13.2 \%$ of the variation in MIP. Cover of native vegetation in removal treatment plots $(104.50 \pm 2.6 \%)$ was greater than that of the control plots $(95.14 \pm 3.66 \%),(\mathrm{P}=0.0236, \mathrm{df}=115)$. These results show that removal of garlic mustard results in an increase in soil MIP and cover of native species; however, there is not a complete loss of MIP associated with garlic mustard invasion. Following removal of garlic mustard, our data suggest that mycorrhizal plants recover more slowly than non-mycorrhizal species, apparently due to a delay in the establishment of a well-functioning mycorrhizal association. Our study is the first to demonstrate that the MIP of native soils and cover of native species increase following reduction in the cover of garlic mustard.
\end{abstract}

Keywords: Garlic mustard, Alliaria petiolata, arbuscular mycorrhizal fungi, mycorrhizal inoculum potential, invasive plant, deciduous forest, corn root bioassay, removal treatments.

\section{INTRODUCTION}

Garlic mustard (Alliaria petiolata) is considered to be among the most troublesome of the invasive plants in the Eastern Deciduous forest of North America (Blossey et al. 2001, Stinson et al. 2006, Rodgers et al. 2008). A Eurasian native, garlic mustard was apparently first introduced into North America on Long Island, New York USA in 1868 (Clapman et al. 1952). However, multiple introductions of the plant into North America (Meekins et al. 2001, Durka et al. 2005) have contributed to relatively high genetic diversity of the species in the introduced range. Garlic mustard has colonized 37 states in USA, but most abundantly in the northeastern and midwestern portions of the USA, and five Canadian Provinces (USDA, NRCS 2009). It is considered to be a threat to the indigenous ground layer in deciduous forest communities.

Several mechanisms have been proposed to explain the success of this highly invasive species: high seed production

*Address correspondence to this author at the School of Biological Sciences, Illinois State University, Normal, Illinois 61790-4120, USA; Tel: 309-438-2653; Fax: 309-438-3722; E-mail: rcander@ilstu.edu

Handling Editor: Jianping $\mathrm{Xu}$ and seedling establishment (Anderson et al. 1996, Byers and Quinn 1998), flowers adapted for generalist pollinators and the ability to successfully self- and cross-pollinate (Anderson et al. 1996, Cruden et al. 1996) with relatively little inbreeding depression (Mullarkey 2009), production of allelopathic compounds that reduce seed germination or plant growth (Vaughn and Berhow 1999, Roberts and Anderson 2001, Prati and Bossdorf 2004), phenotypic plasticity of photosynthesis with high adaptability to varied light regimes (Dhillion and Anderson 1999, Myers and Anderson 2003, Myers et al. 2005), low levels of herbivory in the novel environment due to the presence of protective secondary compounds (Rodgers et al. 2008), and phenological niche separation from most native species during early spring of its second year (Myers and Anderson 2003, Timpe 2007). Research supports all of these hypotheses at least as partial explanations for garlic mustard's success. However, recently there has been an increasing amount of evidence supporting the hypothesis of "novel weapons" (Callaway and Ridenour 2004, Callaway et al. 2005) employed by many invasive plant species, including garlic mustard, to compete effectively against native species in the invaded environment.

Secondary compounds generally are thought to provide protection from herbivory (Karban and Baldwin 1997, 
Baldwin 1998). However, field and laboratory studies showed some of these compounds to be important allelopathic agents that depress germination and growth of competitor plants (Rice 1974, Fitter 2003, Callaway and Ridenour 2004, Abhilasha et al. 2008). In the case of the non-mycorrhizal garlic mustard, they prevent or reduce associations between host plants and AMF and ectomycorrhizal fungi (Roberts and Anderson 2001, Stinson et al. 2006, Stinson et al. 2007, Callaway et al. 2008, Wolfe et al. 2008). Thus, novel chemical weapons deployed by garlic mustard against competing plants may act in a two-fold manner: directly as agents of interference against native plants (Vaughn and Berhow 1999, Meekins and McCarthy 1999, Roberts and Anderson 2001, Prati and Bossdorf 2004) and indirectly as suppressors of mycorrhizal symbionts. Garlic mustard has a stronger negative effect on naïve fungal mutualists in its introduced North American range than it does on mycorrhizae in Europe (Callaway et al. 2008). In the eastern deciduous forest, it is estimated that $70-90 \%$ or more of native plant species form mycorrhizal associations (Berliner and Torrey 1989, Brundett 1991). Loss of the mycorrhizal association can reduce growth, reproductive success, and competitiveness of plant species (Allen 1991, Smith and Read 1997).

The density of garlic mustard was shown to be negatively correlated with the mycorrhizal inoculum potential (MIP) of forest soils (Roberts and Anderson 2001). Soil MIP is a function of AMF spores, extraradical hyphae in soil, and intraradical hyphae within colonized roots, all of which can initiate new colonization when they are contacted by noncolonized roots. As the abundance of non-mycorrhizal garlic mustard increases on a site, and native mycorrhizal host plants decline, soil MIP decreases because the mass of colonized roots declines, resulting in less inoculum present as spores and hyphae in soil and in colonized roots. It is likely that native species may have lower levels of colonization because of a decline in MIP and interference with the formation of AMF associations (Roberts and Anderson 2001).

Some compounds inhibiting establishment of the mycorrhizal associations, such as most glucosinolates and their degradates, and flavonoid glycosides, frequently have halflives less than ten days and $12 \mathrm{~h}$, respectively, in non-sterile soil (Barto and Cipollini 2009a, Barto and Cipollini 2009b). Despite the potentially short residence time of these compounds, extracts of garlic mustard can reduce AMF spore viability by 53 to $89 \%$ (Callaway et al. 2008), and on sites where the abundance of garlic mustard is high there may be a substantial reduction in MIP. Control measures that remove garlic mustard should increase the MIP of the soil and favor mycotrophic native species. Nevertheless, increasing MIP in areas where it has been reduced or where there has been a complete loss of inoculum may be a slow process, even though several authors have indicated that terrestrial vertebrates are important vectors of AMF spores (Gehring et al. 2002) and could effectively disperse spores to areas with depleted inoculum.

We examined the MIP of soil in 2009 taken from plots that had second-year garlic mustard plants removed annually over the last five years (2005-2009). On these plots, removal eventually reduced cover of first- and second-year garlic mustard plants compared to control plots that did not have second-year garlic mustard removed (Bauer et al. 2010). Between 2005 and 2007, the plots were sampled in mid-late May. During this three-year period, total native ground layer cover, cover of the five most abundant native species examined separately, and bare ground were not significantly different in removal plots compared to the control plots (Bauer et al. 2010). In 2008, we sampled our study plots in early spring (April 19-20). To test garlic mustard's effect on spring plants, the species sampled were divided into summer and spring dominant species. There were significant increases in cover of spring dominant species in removal plots compared to control plots on one of our two study sites where spring species were more abundant than summer species (Herold et al. 2010). This is the first time we detected any significant difference in the cover of native plants between removal and control plots, which might be due to a greater intensity of the mycorrhizal association on the removal plots. In this paper, we also compare recovery of selected mycorrhizal and non-mycorrhizal species using the early spring data set. Most of the non-mycorrhizal species are spring dominant species that die back to underground organs by late spring or early summer. Thus, early spring is the only time of the year when the two groups of species could be compared. Because non-mycorrhizal species are affected only by the direct effects of garlic mustard, they should recover sooner than mycorrhizal species which experience direct and indirect effects due to a reduction in the mycorrhizal association, if there is a delay in its recovery. Because of the decline in garlic mustard on removal plots, we predicted the following: (1) MIP and cover of native herbaceous ground layer species would be greater in treatment plots from which garlic mustard plants had been removed than on control plots and (2) nonmycorrhizal species would recover sooner following removal of garlic mustard than mycorrhizal species.

\section{METHODS}

\section{Study Site}

Our study site is located in a second-growth hardwood forest in the ParkLands Foundation's Merwin Nature Preserve, $30 \mathrm{~km}$ northeast of Normal, Illinois, USA. Prior to acquisition of the property by the Foundation in 1970, the site was subject to selective logging and grazing. Study sites include well-established populations of garlic mustard and are located on an upland site and a site in a low-lying area near a creek. As previously noted, even though we removed second-year garlic mustard from our treatment plots for five years, garlic mustard was still present, albeit at lower densities in removal plots than in control plots. Continued presence of garlic mustard on removal plots results from a garlic mustard seed bank that may persist for at least 2-3 years or longer (Baskin and Baskin 1992, Rodgers et al. 2008). In addition, there may be some seed dispersal into removal treatment plots from areas outside the treatment plot as was suggested by Slaughter et al. (2007) in their study.

For this study, we sampled the soil MIP from only the upland site. Differences in herbaceous vegetation between treatment and control plots are reported only from this site for the 2009 sample. This site was chosen for study because 
it contained a well developed herbaceous spring ground layer, whereas the low lying site did not. Both sites have a well developed herbaceous summer ground layer.

\section{Experimental Design}

The experimental design is a randomized complete block design with blocks nested within sites. More complete details of the sampling design are provided in Bauer et al. (2010) and are summarized here. Each of our two study sites has two blocks (approximately $23 \times 30 \mathrm{~m}$ ) each containing 60 plots for a total of 120 study plots per site. Each plot has a treatment area $(2.5 \times 2.5 \mathrm{~m})$ and a centrally located sampling area $(50 \times 50 \mathrm{~cm})$. Parallel transects were located $5 \mathrm{~m}$ apart in each block and plots were placed at 2.5-m intervals along each transect at a random distance of up to $50 \mathrm{~cm}$ right or left of the transects resulting in a minimum buffer strip of 1.5 $\mathrm{m}$ between plot rows. We did not test the MIP with and without garlic mustard present in our study area. The study site has had well established populations of garlic mustard since at least 1988. Consequently, areas without garlic mustard may have had garlic mustard growing on them in the past and would not provided a true test of what the MIP should be in areas that never supported garlic mustard. In each block, one-third of the treatment plots (20) were randomly assigned to a control or one of the two treatments in which second-year plants were hand weeded either early (March 4-9) or late (May 15-18). In early-treatment plots, all second-year garlic mustard plants were removed before garlic mustard seeds had germinated, second-year plants were in the rosette stage, and nearly all native species were dormant. In late-treatment plots, all second-year plants were removed after they had bolted, flowering was occurring, and native species were actively growing. Occasional rosettes were missed at the time of treatment application. However, sampling of plots occurred at a later date and these plants were removed before seeds were released. Thus, seed input from second-year plants growing directly on the plots after 2004 was little to none. Treatments were applied in 20052009 following a pre-treatment sample of vegetation in plots in 2004. For pretreatment data there were no significant differences in the cover of garlic mustard or native vegetation between treatment or control plots. However, control plots had significantly more cover of garlic mustard plants than treatment plots after 2007, but there were no significant differences in cover of native plants between 2004 and 2007 (Bauer et al. 2010).

\section{Data Collection}

\section{Soil Mycorrhizal Inoculum Potential (MIP)}

Soil samples used to determine MIP were collected on 5 May 2009 from five randomly selected early and late removal treatment plots and six randomly selected control plots in each of the two blocks on the upland study site. A soil tube was used to extract two or three soil cores $(2.5 \mathrm{~cm}$ diameter and 10-13 cm deep) from within four $\mathrm{dm}^{2}(10 \times 10$ $\mathrm{cm})$ quadrats. One $\mathrm{dm}^{2}$ quadrat was located $50 \mathrm{~cm}$ from the center of the sample area in each of the four cardinal directions. Soil from the four samples per plot was placed in a single ziplock plastic bag and transported to a walk-in-cold room that was maintained at $10^{\circ} \mathrm{C}$.

\section{Cover of Garlic Mustard}

Aerial cover of first- and second-year garlic mustard (combined) was estimated within the $\mathrm{dm}^{2}$ quadrats from which soil cores for MIP determination were extracted. For analysis of these data, the average cover of garlic mustard in the four $\mathrm{dm}^{2}$ quadrats was used. These data provided information about the abundance of garlic mustard in the quadrats from which soil cores were extracted for MIP analysis. The abundance of garlic mustard previously was shown to be negatively correlated with soil MIP (Roberts and Anderson 2001). The number of $\mathrm{dm}^{2}$ quadrats with cover of garlic mustard at each plot was totaled and used to provide information about the frequency of occurrence of garlic mustard near the sample plots.

\section{Ground Layer Vegetation}

All sampling areas within the two blocks of the upland site were sampled in late spring (May 27-29, and 31) of 2009. Because of a tree fall on one plot the sample size was reduced to 119. Percent aerial cover of all plants rooted within the sampling areas $(50 \times 50 \mathrm{~cm})$ was estimated by species or by genus for Sedges (Carex) and Violets (Viola). Cover of first- and second-year garlic mustard was also estimated. To determine differences in cover of native species and first-year garlic mustard between removal and control plots, these data $(n=119)$ were used rather than data from the 32 plots selected for MIP analysis to maximize sample size.

The effect of removal of garlic mustard on mycorrhizal and non-mycorrhizal species was tested by comparing treatment effects on the combined cover of the three most abundant species of each group using data collected on 19 and 20 April. The three mycorrhizal species were Elymus virginicus (Virginia wild rye), Festuca obtusa (nodding fescue), and Sanicula gregaria (black snakeroot) and Claytonia virginica (spring beauty), Dentaria laciniata, (toothwort) and Floerkea prospinacoides (false mermaid weed) were the three most abundant non-mycorrhizal species.

\section{Corn Root Bioassay to Assess MIP}

A corn root bioassay (Sweet corn -Sunglow 63 days) was used to assess the MIP of the collected soil (Moorman and Reeves 1979). Corn forms mycorrhizal associations with many species of AMF and has uniform and rapid growth. Therefore, it has advantages over the use of native species in bioassays, which can have greater specificity for AMF fungi, when general surveys of all types of viable mycorrhizal fungal propagules are conducted (Korb et al. 2003). Corn kernels were rinsed in deionized water and placed in a finger bowl on May 6, 2009 containing deionized water. The finger bowl was maintained at $30^{\circ} \mathrm{C}$ in the dark for $24 \mathrm{~h}$ to allow the seeds to germinate before they were used in the bioassay. On May 7, unamended soil $(165 \mathrm{cc})$ from each sample was placed in a cone-tainer on a greenhouse bench and one germinated corn kernel (radical was visible) was planted a few $\mathrm{mm}$ below the soil surface. A thin layer of perlite was added to the surface of the soil to reduce moisture loss and the planted seeds were watered twice daily. Fourteen hours of supplemental lighting was provided to the growing plants in the greenhouse. Plants were grown for 21 days and then 
the roots were harvested and gently washed free of soil. The entire root system was cut into $1-\mathrm{cm}$ segments and a $0.25 \mathrm{~g}$ fresh weight sample was placed in a plastic cassette for clearing and staining using the methods of Vierheilig et al. (1998). One-hundred 1-cm segments of stained roots of each sample were scored as having mycorrhizal structures (coenocytic hyphae, pelotons, vesicles, or arbuscules) using the gridline intersection method (Giovannetti and Mosse 1980).

\section{Data Analysis}

Because the primary interest of this study was to compare plots in which garlic mustard was removed with control plots, the late and early removal treatments were combined. All data were tested to determine if the assumptions of ANOVA were met using Shapiro-Wilk tests of normality and plots of residuals over the predicted values. Nontransformed total cover of native vegetation and square root transformed MIP met the assumptions and were analyzed with two-way ANOVA with block as a main effect and treatment nested within blocks. The effect of garlic mustard removal on the combined cover (logn transformed) of the three leading mycorrhizal and non-mycorrhizal species was analyzed using MANOVA with treatment nested within blocks. These data did not meet the assumption of normality with the Shapiro-Wilk test $(\mathrm{P}>0.03)$. However, the normality and box plots of the residuals were acceptable and MANOVA is robust to violations from normality (Scheiner 2001). When appropriate, lsmeans followup tests with a Bonferroni correction were used to test for differences among treatments, except for the planned comparisons for mycorrhizal and non-mycorrhizal species comparisons. The planned comparisons tested differences between means for control and removal plots for mycorrhizal and nonmycorrhizal groups separately in each block using Tukey tests. However, none of remaining data sets met the assumptions even after transformation (logn, arcsin, square root). Therefore, Kruskal Wallace non-parametric ANOVA was used to analyze these data. All data were analyzed using SAS 9.1 (SAS Institute, Inc. 2002-2003).

\section{RESULTS}

\section{Decimeter Quadrats}

\section{Cover of Garlic Mustard}

Within the $\mathrm{dm}^{2}$ quadrats, from which soil samples for determining MIP were taken, there was a significant $(\chi 2=$ 11.2967, $\mathrm{df}=1, \mathrm{P}=0.0008)$ effect of treatment on cover of garlic mustard. Removal treatment plots $(0.25 \pm 0.11 \%$, mean $\pm \mathrm{SE}$ ) had less cover of garlic mustard than control plots $(3.75 \pm 1.07 \%)$.

\section{Occurrence of Garlic Mustard}

The number of $\mathrm{dm}^{2}$ quadrats in which garlic mustard occurred at each plot was significantly $\left(\chi^{2}=6.0954, \mathrm{df}=1, \mathrm{P}\right.$ $=0.0136)$ greater for control plots $(1.25 \pm 0.32)$ than removal treatment plots $(0.45 \pm 0.16)$. The percentage of $\mathrm{dm}^{2}$ containing garlic mustard were $31.3 \%$ and $11.3 \%$ for control and removal plots, respectively.

\section{Sample Plots $(50$ x $50 \mathrm{~cm})$}

\section{Cover of Native Vegetation}

For total cover of native vegetation in all $50 \times 50 \mathrm{~cm}$ sample areas in both blocks $(n=119)$, there were significant effects for block $\left(\mathrm{F}_{1,115}=25.24, \mathrm{P}<0.0001\right)$ and treatments nested within blocks $\left(\mathrm{F}_{2,115}=3.26, \mathrm{P}=0.0418\right)$. Removal treatment plots had a significantly $(\mathrm{P}=0.0236$, df $=115)$ greater percent cover than the control plots $(104.5 \pm 2.60 \%$ and $95.14 \pm 3.66 \%$, respectively) and block two had significantly $(\mathrm{P}<0.0001$, df $=115)$ greater total cover of native species than block one $(112.41 \pm 3.03 \%$ and $90.64 \pm 2.33 \%$, respectively).

\section{Cover of First-year Garlic Mustard}

The cover of first-year garlic mustard was significantly $\left(\chi^{2}=45.31\right.$, df $\left.=1, \mathrm{P}<0.001\right)$ greater in control plots $(2.78 \pm$ $0.35 \%)$ than removal plots $(0.34 \pm 0.06 \%$, respectively).

Comparison of Mycorrhizal and Non-mycorrhizal Plants. MANOVA indicated significant treatment nested within block effects $\left(\mathrm{F}_{6,230}=10.06, \mathrm{P}<0.0001\right)$. Only the first eigenvector was significant and it accounted for 94.3 percent of the variation. Standard Canonical Coefficients showed that mycorrhizal plants (1.020) were more important than non-mycorrhizal plants $(0.469)$ in causing differences in treatments nested within blocks. Non-mycorrhizal plants had greater cover in removal plots than control plots in block 2 . None of the other planned comparison between removal and control plots was significant, although cover was greater in removal than control plots for all comparisons (Fig. 1).

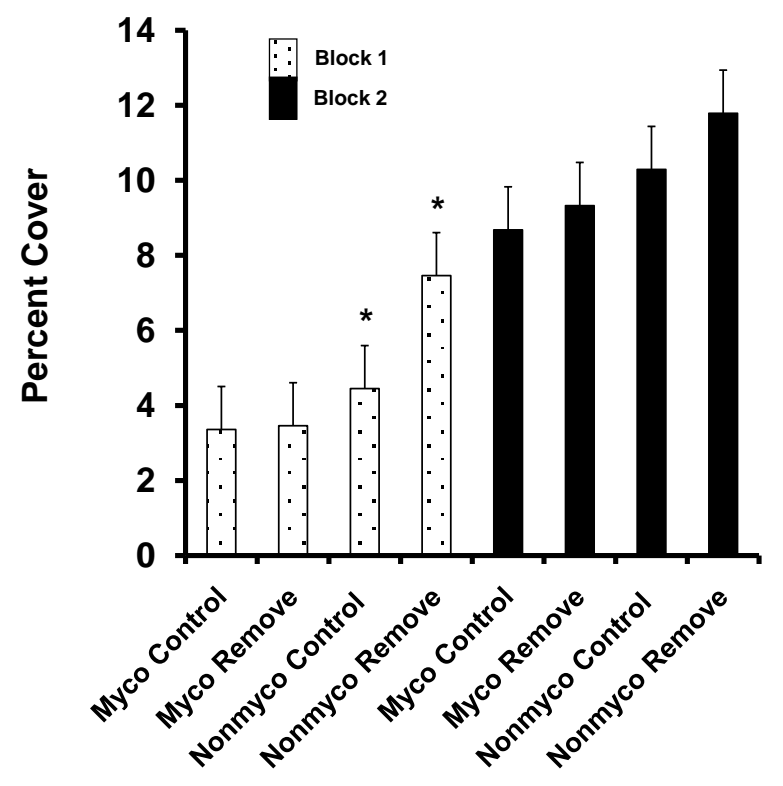

\section{Treatment}

Fig. (1). Effect of removal of garlic mustard on cover (mean \pm SE) of mycorrhizal and non-mycorrhizal plants. Comparisons marked with an asterisk are significantly different.

\section{Mycorrhizal Inoculum Potential (MIP)}

There was a significant $\left(\mathrm{F}_{2,28}=3.43, \mathrm{P}=0.0465\right)$ effect of treatment nested within block for MIP, but there was no 
significant effect of block $\left(\mathrm{F}_{1,28}=1.56, \mathrm{P}=0.2220\right.$. Removal treatment plots had significantly $(\mathrm{P}=0.0240, \mathrm{df}=28)$ greater MIP than control plots $(25.72 \pm 2.26 \%$ and $18.29 \pm 2.04 \%$, respectively). Cover of garlic mustard in the $\mathrm{dm}^{2}$ quadrats was negatively correlated $\left(\mathrm{r}^{2}=0.1325, \mathrm{P}<0.05, \mathrm{df}=30\right)$ with plot MIP and accounted for $13.2 \%$ of the variation in MIP.

\section{DISCUSSION}

Several studies have shown that garlic mustard reduces or prevents formation of the mycorrhizal association (Roberts and Anderson 2001, Stinson et al. 2006, Stinson et al. 2007, Callaway et al. 2008, Wolfe et al. 2008) and Roberts and Anderson (2001) reported a negative correlation between cover of garlic mustard and soil MIP under field conditions. However, no previous studies have shown that MIP of native soils and cover of native species increase following a reduction in cover of garlic mustard. Our data showed that following removal of garlic mustard native vegetation began recovery as indicated by an increase in cover of native species in removal plots compared to control plots. First-year plants were still present on removal plots in 2009 , although their cover on the sample areas $(50 \times 50 \mathrm{~cm})$ and total cover and the frequency of occurrence of garlic mustard in $\mathrm{dm}^{2}$ quadrats were greater in control than removal plots. Nevertheless, the $28.8 \%$ reduction in MIP in control versus removal plots we report here appears to be consistent with the reduction in viability $(-20 \%$ to $-66 \%)$ and infectivity $(-16 \%$ to $-66 \%)$ of AMF spores from four regions of North America in soils pre-conditioned with garlic mustard in a greenhouse study (Callaway et al. 2008).

Nearly all summer dominant species on our study site were reported to be mycorrhizal (Berliner and Torrey 1989, Brundrett and Kendrick 1988, Brundrett 1991, DeMars 1996, Roberts 1997). We have added to the list of mycorrhizal plant species on our study plot with additional survey work (Borowicz, unpublished). Delay in the recovery of native vegetation after annual removal of garlic mustard was initiated in 2005 may be related to several factors, including occurrence of a seed bank for garlic mustard that may take 23 years or longer to be depleted (Baskin and Baskin 1992, Nuzzo 1991, McCarthy 1997, Rodgers et al. 2008), and the length of time required for the mycorrhizal association to become well-established following a decline in the abundance of garlic mustard. A decline in the levels of AMF colonization may reduce growth rates of native mycotrophic species and retard the rate at which they can reoccupy space vacated by garlic mustard. Our data supports this assumption and suggests that non-mycorrhizal species may recover from garlic mustard removal sooner than mycorrhizal species. Although we found statistically significant evidence for this relationship in only one of two blocks of our study site, in each planned comparison removal plots had greater cover than control plots albeit these differences were small for some comparisons. Although AMF are generally assumed to function in facilitating nutrient uptake in nutrient-poor soils, AMF can improve water relations under drought conditions (Dell'Amico et al. 2002, Augé 2004) and alter resistance and tolerance of plants to pathogens (Borowicz 2001, Pozo and
Azcón-Aquilar 2007), insect herbivores (Borowicz 1997, Gange 2001, Bennett and Bever 2007, Koricheva et al. 2009), and improve tolerance of native plants to garlic mustard's allelopathic effect (Barto et al. 2010). Consequently, suppression or compositional change in the AMF community may have unanticipated effects on host plants, which can then feed back to the fungal community (Bever 2002, Gehring and Bennett 2009). Studies are needed to determine how removal of garlic mustard affects the composition of the AMF community (Burke 2008), the level of AMF colonization in roots of native species and inorganic nutrients dynamics associated with reduced levels of AMF mycorrhizae in roots of native species. Reduction of AMF may decrease inorganic nutrient uptake by mycorrhizal plant species, thereby increasing nutrient availability to nonmycorrhizal species including garlic mustard. Experimentally the direct and indirect effects of garlic mustard competition on native species should be delineated.

\section{REFERENCES}

Anderson, RC, Dhillion, SS \& Kelley, TM (1996) Aspects of the ecology of an invasive plant, garlic mustard (Alliaria petiolata), in central Illinois. Restoration Ecology, 4, 181-91.

Auge, RM (2004) Arbuscular mycorrhizae and soil/plant water relations. Canadian Journal of Soil Science, 84, 373-81.

Abhilasha, D, Quintana, N, Vivanco, T \& Joshi, J (2008) Do allelopathic compounds in invasive Solidago canadensis s.l. restrain the native European flora? Journal of Ecology, 96, 993-01.

Allen, MF (1991) The ecology of mycorrhizae. Cambridge University Press, New York.

Baldwin, IT (1998) Jasmonate-induced responses are costly but benefit plants under attack in native populations. Proceeding of the National academy of Science USA, 95, 8113-18.

Barto, EK \& Cipollini, D (2009a) Density-dependent phytotoxicity of Impatiens pallida plants exposed to extracts of Alliaria petiolata. Journal of Chemical Ecology, 35, 495-04.

Barto, EK \& Cipollini, D (2009b) Field soil concentrates and half-lives of Alliaria petiolata secondary metabolites. Chemosphere, 76, 71-75.

Barto, EK, Friese, C \& Cipollini, D (2010) Arbuscular mycorrhizal fungi protect a native plant from allelopathic effects of an invader. Journal of Chemical Ecology, DOI 10.1007/s10886-010-9768-4.

Baskin, JM \& Baskin, CC (1992) Seed germination biology of the weedy biennial Alliaria petiolata. Natural Areas Journal, 12, 191-97.

Bauer, JT, Anderson, RC \& Anderson, MR (2010) Competitive interactions among first-year and second-year plants of the invasive, biennial garlic mustard (Alliaria petiolata) and native ground layer vegetation. Restoration Ecology Early View (February 2009) on line. http://www3.interscience.wiley.com/journal/122197837/abstract?C RETRY=1\&SRETRY=0. Accessed 18 December 2009.

Bennett, AE \& Bever, JD (2007) Mycorrhizal species differentially alter plant growth and response to herbivory. Ecology, 88, 210-18.

Berliner, R \& Torrey, JC (1989) Studies on mycorrhizal associations in Harvard Forest. Canadian Journal of Botany, 67, 2245-51.

Bever, JD (2002) Negative feedback within a mutualism: Host-specific growth of mycorrhizal fungi reduces plant benefit. Proceedings of the Royal Society of London, 269, 2595-01.

Blossey, F, Nuzzo, V, Hinz, H \& Gerber, E (2001) Developing biological control of Alliaria petiolata (M. Bieb.) Cavara and Grande (Garlic Mustard). Natural Areas Journal, 21, 357-67.

Borowicz, VA (1997) A fungal root symbiont modifies plant resistance to an insect herbivore. Oecologia, 112, 534-42.

Borowicz, VA (2001) Do arbuscular mycorrhizal fungi alter plant-pathogen relations? Ecology, 82, 3057-68.

Brundrett, M (1991) Mycorrhizas in natural systems. In Begon, M, Fitter, AH \& MacFayden, A (Eds.). Advances in Ecological Research, 21, 171-313. 
Brundrett, MC \& Kendrick, B (1988) The mycorrhizal status, root anatomy, and phenology of plants in a sugar maple forest. Canadian Journal of Botany, 66, 1153-73.

Burke, DJ (2008) Effects of Alliaria petiolata (garlic mustard; Brassicaceae) on mycorrhizal colonization and community structure in three herbaceous plants in a mixed deciduous forest. American Journal of Botany, 95, 1416-1425.

Byers, DL \& Quinn, JA (1998) Demographic variation in Alliaria petiolata (Brassicaceae) in four contrasting habitats. Journal of the Torrey Botanical Society, 125, 138-49.

Callaway, RM \& Ridenour, WM (2004) Novel weapons: invasive success and the evolution of increased competitive ability. Frontiers in Ecology and the Environment, 2, 436-43.

Callaway, RM, Hierro, JL \& Thorpe, AS (2005) Evolutionary trajectories in plant and soil microbial communities: Centaurea invasions and the geographic mosaic of coevolution. In: Sax, DF, Gaines, SD \& Stachowicz, JJ (Eds). Exotic species invasions: insights into ecology, evolution and biogeography. Sinauer, Sunderland, Massachusetts, USA pp. 341-363.

Callaway, RM, Cipollini, D, Barto, K, Thelen, GC, Hallett, SG, Prati, D, Stinson, K \& Klironomos, J (2008) Novel weapons: invasive plants suppress fungal mutualists in America but not in its native Europe. Ecology, 89, 1043-55.

Clapman, AR, Tutin, TG \& Warburg, WF (1952) The flora of the British Isles. Cambridge University Press, Great Britain.

Cruden, RW, McClain, AM \& Shrivastava, GP (1996) Pollination biology and breeding system of Alliaria petiolata (Brassicaceae). Bulletin of the Torrey Botanical Society, 123, 272-80.

Dell'Amico, J, Torrecillas, A, Rodríguez, P, Morte, A \& Sánchez-Blanco, J (2002) Responses of tomato plants associated with the arbuscular mycorrhizal fungus Glomus clarum during drought and recovery. Journal of Agricultural Science, 138, 387-93.

DeMars, B (1996) Brief Note: Vesicular-Arbuscular Mycorrhizal Status of Spring Ephemerals in Two Ohio Forests. The Ohio Journal of Science, 96, 97-99.

Dhillion, SS \& Anderson, RC (1999) Growth and photosynthetic response of first year garlic mustard (Alliaria petiolata) to varied irradiance. Journal of the Torrey Botanical Society, 126, 9-14.

Durka, WO, Bossdorf, D, Prati, D \& Auge, H (2005) Molecular evidence for multiple introductions of garlic mustard (Alliaria petiolata, Brassicaceae) to North America. Molecular Ecology, 14, 1697-06.

Fitter, A (2003) Making allelopathy respectable. Science, 301, 1337-38.

Gange, AC (2001) Species-specific responses of a root- and shoot-feeding insect to arbuscular mycorrhizal colonization of its host plant. New Phytolologist, 150, 611-18.

Gehring, CA, Wolf, JE \& Theimer, TC (2002) Terrestrial vertebrates promote arbuscular mycorrhizal fungal diversity and inoculum potential in a rain forest soil. Ecology Letters, 5, 540-48.

Gehring, C \& Bennett, A (2009) Mycorrhizal fungal-plant-insect interactions: the importance of a community approach. Environmental Entomology, 38, 93-02.

Giovannetti, M \& Mosse, B (1980) An evaluation of techniques for measuring vesicular-arbuscular mycorrhizal infection in roots. New Phytologist, 84, 489-500.

Herold, J, Anderson, MR, Bauer, JT, Borowicz, VA \& Anderson, RC (2010) The effect of removal of second-year garlic mustard (Alliaria petiolata) on deciduous forest spring and summer dominant herbaceous groundlayer species in central Illinois, USA. In review. Ecological Restoration.

Karban, R \& Baldwin, IT (1997) Induced response to herbivory. University of Chicago Press, Chicago.

Korb, JE, Johnson, NC \& Covington, WW (2003) Arbuscular mycorrhizal propagules densities respond rapidly to ponderosa pine restoration treatments. Journal of Ecology, 40, 101-10.

Koricheva J, Gange, AC \& Jones, T (2009) Effects of mycorrhizal fungi on insect herbivores: a meta-analysis. Ecology, 90, 2088-97.

McCarthy, BC (1997) Responses of a forest understory community to experimental removal of an invasive nonindigenous plant (Alliaria petiolata, Brassicaceae). In: Luken, J \& Thieret, J (Eds.). Assessment and management of plant invasions. Springer-Verlag, New York.
Meekins, J \& McCarthy, B (1999) Competitive ability of Alliaria petiolata (garlic mustard, Brassicaceae), an invasive nonindigenous forest herb. International Journal of Plant Sciences, 160, 743-52.

Meekins, JF, Ballard, HE Jr, \& McCarthy, BC (2001) Genetic variation and molecular biogeography of a North American invasive plant species (Alliaria petiolata, Brassicaceae). International Journal of Plant Sciences, 162, 161-69.

Moorman, T \& Reeves, F (1979) The role of endomycorrhizae in revegetation practices in the semi-arid west. II. A bioassay to determine the effect of land disturbance on endo mycorrhizal populations. American Journal of Botany, 66, 14-18.

Mullarkey, A (2009) Inbreeding depression and partitioning of genetic load in the invasive biennial, Alliaria petiolata (garlic mustard). MS Thesis, School of Biological Sciences, Illinois State University, Normal, IL.

Myers, CV \& Anderson, RC (2003) Seasonal Variation in Photosynthetic Rates Influences Success of an Invasive, Exotic Plant, Garlic Mustard (Alliaria petiolata). The American Midland Naturalist, 150, 231-45.

Myers, CV, Anderson, RC \& Byers, DL (2005) Influence of shading on the growth and leaf photosynthesis of the invasive non-indigenous plant garlic mustard [Alliaria petiolata (M.Bieb.) Cavara and Grande] grown under simulated late-winter to mid-spring conditions. Journal of the Torrey Botanical Society, 132, 1-10.

Nuzzo, VA (1991) Experimental Control of Garlic mustard [Alliaria petiolata (Bieb.) Cavara and Grande] in Northern Illinois Using Fire, Herbicide and Cutting. Natural Areas Journal, 11, 158-167.

Prati, D \& Bossdorf, P (2004) Allelopathic inhibition of germination by Alliaria petiolata (Brassicaceae). American Journal of Botany, 91, 285-88.

Pozo, MM \& Azcón-Aquilar, C (2007) Unraveling mycorrhiza-induced resistance. Current Opinion in Plant Biology, 10, 393-98.

Rice, EL (1974) Allelopathy. Academic, New York.

Roberts, KJ (1997) An examination of the interactions between garlic mustard [Alliaria petiolata (Bieb.) Cavara \& Grande] and vesicular-arbuscular mycorrhizal (VAM) fungi. Ph.D. Dissertation, Illlinois State University, Department of Biology, Normal, IL.

Roberts, KJ \& Anderson, RC (2001) Effect of garlic mustard [Alliaria petiolata (Beib. Cavara \& Grande)] extracts on plants and arbuscular mycorrhizal (AM) fungi. American Midland Naturalist, 146, 146-52.

Rodgers, VL, Stinson, KA \& Finzi, AC (2008) Ready or not, garlic mustard is moving in: Alliaria petiolata as a member of eastern North American forests. BioScience, 58, 426-36.

SAS Institute Inc. (2002-2003) SAS 9.1.3 Help and Documentation, Cary, NC: SAS Institute Inc., 2002-2004.

Scheiner, SM (2001) MANOVA: Multiple response variables and multispecies interactions. In: Scheiner, SM \& Gurevitch, J (Eds.). Design and analysis of ecological experiments. Oxford University Press, Oxford, UK, pp. 99-115.

Slaughter, BS, Hochstedler, WW, Gorchov, DL \& Carlson, AM (2007) Response of Alliaria petiolata (garlic mustard) to five years of fall herbicide application. Journal of the Torrey Botanical Society, 134, 18-26.

Smith, SE \& Read, DJ (1997) Mycorrhizal symbiosis. 2nd ed. New York: Academic Press.

Stinson, KA, Campbell, SA, Powell, JR, Wolfe, BE, Callaway, RM, Thelen, GC, Hallet, SG, Prati, D \& Klironomos, JN (2006) Invasive plant suppresses the growth of native tree seedlings by disrupting belowground mutualisms. PLoS Biology, 4, 727-31.

Stinson, KA, Kaufman, S, Durbin, L \& Lowenstein, F (2007) Impacts of garlic mustard invasion on a forest understory community. Northeastern Naturalist, 14, 73-88.

Timpe, M (2007) Phenological niche separation increases reproductive success of the herbaceous exotic invader Alliaria petiolata (garlic mustard). MS Thesis. Department of Biological Sciences. Illinois State University, Normal, IL.

USDA, NRCS. (2009) The PLANTS Database (http://plants.usda.gov, accessed 3 October 2009). National Plant Data Center, Baton Rouge, LA 70874-4490 USA.

Vaughn, S \& Berhow, MA (1999) Allelochemicals isolated from tissues of the invasive weed garlic mustard (Alliaria petiolata). Journal of Chemical Ecology, 25, 2495-04. 
Vierheilig, H, Coughlan, A, Wyss, U \& Piche, Y (1998) Ink and vinegar, a simple staining technique for arbuscular-mycorrhizal fungi. Applied and Environmental Microbiology, 64, 5004-07.
Wolfe, BE, Rodgers, VL, Stinson, KA \& Pringle, A (2008) The invasive plant Alliaria petiolata (garlic mustard) inhibits ectomycorrhizal fungi in its introduced range. Journal of Ecology, 96, 777-83.

Received: March 13, 2010

Revised: May 04, 2010

Accepted: May 14, 2010

(C) Anderson et al.; Licensee Bentham Open.

This is an open access article licensed under the terms of the Creative Commons Attribution Non-Commercial License (http://creativecommons.org/licenses/by$\mathrm{nc} / 3.0 /$ ), which permits unrestricted, non-commercial use, distribution \& reproduction in any medium, provided the work is properly cited. 